Youhanna Nessim Youssef

Australian Catholic University

Brisbane

Youhanna.Youssef@acu.edu.au

\title{
LITANIES OR PRAYERS FOR TRAVELLERS
}

\section{INTRODUCTION}

Travelling in ancient times was very risky. This fact is attested by the collection of miracles associated with travel; such as the miracle of Saint Menas, ${ }^{1}$ the Arabic version of the miracle of Saint Philotheus ascribed to Severus of Antioch, ${ }^{2}$ the miracle mentioned in the book of the Forty Biographies, ${ }^{3}$ and a miracle performed by Cosma and Damian. ${ }^{4}$ It is recorded that Nestorius had complained about having to travel, saying that he was too old (he must have been over sixty at this time), unwell, had suffered from the hazards of travel, and that his hand and side had been mangled. ${ }^{5}$

The litanies ${ }^{6}$ for the travellers occur in the Euchologion for the matins. Except on Saturdays, Sundays and the feasts of the Lord, the Litany for the Travellers is said after the Litany for the Sick, during the offering of the Morning Incense. ${ }^{7}$ It is also said during the consecration of altars, ${ }^{8}$ during Baptism, ${ }^{9}$ during the consecration of the

(1) J. DresCHER, Apa Mena, a selection of CopticTextsrelating to Saint Menas (Textes et documents), Cairo, 1946, pp. 116-117.

(2) Youhanna Nessim Youssef, "The Encomium of St. Philotheus ascribed to Severus of Antioch," Coptica, 1 (2002), pp. 169-221, and especially pp. 189-198.

(3) Bishop SAMUEL, كتاب الاربعين خبر [The book of the forty biographies], Cairo, 1999 , p. 46.

(4) Information kindly provided by the late R. F. M. Van Esbroeck in 2000.

(5) D. JOHNSON, "Nestorius," CE, 6, pp. 1786-1787.

(6) Emile Maher IsHaQ, "Awshiyah," CE, 1, p. 311.

(7) Archbishop BASILIOS, "Gloria in Excelsis," CE, 4, p. 1147.

(8) Archbishop BASILIOS, "Altar, consecration of," CE, 1, pp. 108-109.

(9) Archbishop BAsILIOS, "Baptism, Liturgy of," CE, 2, pp. 339-342. 
water in the baptismal font, ${ }^{10}$ and during the liturgy of the Epiphany:11

\section{Priest}

Tent2O OYO2 TEnTwB2

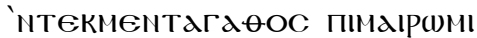
apıфмеүI пбоlс 'nneNIO† нем nеNсnноү етаү(D) еп()еммо

Deacon

T⿰в2 EXEN neNIO† neM

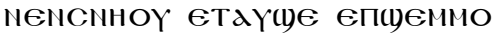

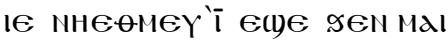
NIBEN COYTWN NOYMDIT THPOY ITE еволгітеN фіом IE NILршоY

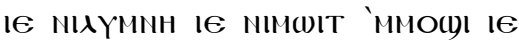

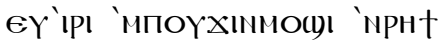

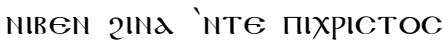
пennoYt Tacenor

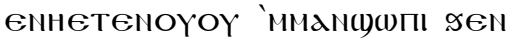
OY2IPHNH 'nTEgXa nenNOBI Nan EROג

People

KYPle EגeHCON

Priest

le nhe emel elue gen mal niren COYTWI HOYMUIT THPOY ITE

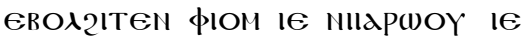

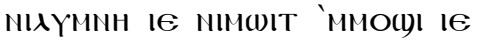

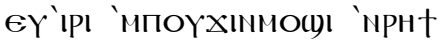
nibell OYON MIBEN ETgEN Mal NIBEN MaT中wOY ESOYH ЕоүАүмнн 'мхамн ЕоүАүмнн 'nte moyxal
We ask and entreat Your goodness, $\mathrm{O}$ lover of mankind, remember $\mathrm{O}$ Lord our fathers and our brethren who are travelling.

Pray for our fathers and our brethren who are travelling, and those who intend to travel anywhere. Make straight all their ways whether by sea, rivers, lakes, roads, or those who are travelling by any other means, that Christ our God may bring them back to their own homes in peace, and forgive us our sins.

\section{Lord have mercy}

And those who intend to travel anywhere, make straight all their ways, whether by sea, rivers, lakes, roads or those who are travelling by any other means, everyone, anywhere. Lead them into a harbour of calm, a harbour of salvation. 343.

(10) Archbishop BASILIOS, "Baptistery, consecration of," CE, 2, pp. 342-

(11) Archbishop BASILIOS, “Epiphany, Liturgy of," CE, 3, pp. 967-968. 
aPIKdTAzION aPIC)фIP

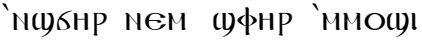

NEMUOY

MHITOYE nHETENOYOY SEN

OYPd(Dı EYPd(Dı sen OYTOYXO

EYTOYXHOYT

аріс)фнр 'нергшв nем nекевідік

geN 2 WB NIBEN 'NAГגөON

ANON $\lambda \epsilon 2 \omega N$ ПбOIC

тепметрем 'nхшіג етяеN

IalBioc pal ape2EPOC

'NATEвגdвH 'NATXIMON

'NdT(D)өертер ()גевоג

People

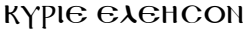

Priest

SEN ПI2MOT NEM NIM ET(DEN2HT

nем †нетмаром 'nте

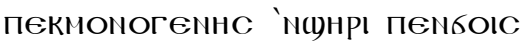

OYO2 пеNnOY十 OYO2 пеNCWTHр

iнcoYc піхрістос фal ете

євод2Ітотч ЕРє ПІшоY
Graciously accompany them in

their departure and be their companion in their travel.

Bring them back to their own, joyfully rejoicing and safe being secure.

Be a fellow worker with Your servants in every good deed. As for us too, O Lord, keep our sojourn in this life without harm, without storm, and undisturbed to the end.

\section{Lord have mercy}

By the grace, compassion and love for mankind of Your Only begotten Son, our Lord, God and Saviour Jesus Christ.

Through whom is the glory.

The Morning Litany of the Holy Week: ${ }^{12}$

Twв2 Exen nenIO† neM

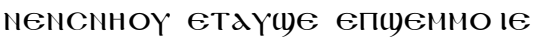

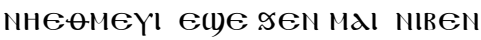
COYTWN NOYMUIT THPOY ITE

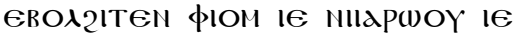
NIXYMNH IE nIMUIT "MMODI le EYIPI ‘ мПОYXINMOWI ' NPH† NIBEN 2Ind 'nTE $\Pi \bar{\kappa} \overline{\mathrm{C}}$
Pray for our fathers and brethren who are travelling anywhere or who intend to travel, that God may facilitate all their ways, whether by sea or river, or lake, or tracks or those travelling by all means. That Christ our Lord may bring them back to

(12) Attallah Arsenius AL-MuHARRAQI, كتاب دلال أسبوع الالام المشتمل على ترتيب [The order of the Passion Week which includes the order of the Passion Week from Saturday of Lazarus to Šam alNasim ], Cairo, 1970, p. 128. 


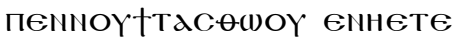
NOYOY MANCDEI gEN OY2IPHNH $\overline{\mathrm{N}} \overline{\mathrm{T}} \overline{\mathrm{C}}$ their homes in safety and forgive our sins.

The Evening Litany of the Holy Week:

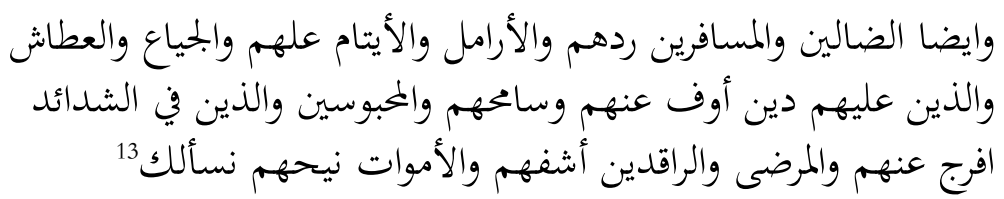

And also those who are led astray, and the travellers allow them to return back, support the widows and the orphans and give plenty to those in poverty. Those who are in debt, pay their debts. Forgive them and those who are in distress, give them comfort. Heal the sick and repose the departed, we ask You O Lord...

\section{THE MANUSCRIPT}

The description according to W. E. Crum: ${ }^{14}$

"Or 435 - Paper; a bound volume, containing parts of two MSS.; (a) fol. 1 paged i - 14; (b) 15 paged RI, -46 . The fol. of (a) are not consecutive. Both fragments were also paged consecutively with Syriac letters from the backward, fol. 43 being. also, what is "fol. 43 being." The text of (a) in 15 (cf. Hyvernat, pl. iii.e for the type of both). Arabic version is given for the rubrics only. The usual initials, titles and the letters $\phi, 9$, are in red.

(a) Services for the Consecration of a Subdeacon (fol. 1) Hegumen

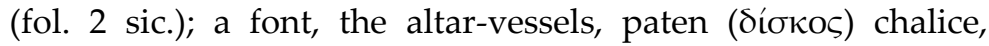
spoon ( $\mu \nu \sigma \tau \eta \dot{\rho})$, an icon, martyrs' relics, reconsacration altar (fol. 5ff.).

(b) Services for the Consecration of a baptismal font (the end only), the text being quite different from the ordinary (fol. 15 cf. Tuki, Euch. Ii $\overline{\mathrm{c}} \bar{\lambda} \overline{\mathrm{z}})$; of the paten, chalice, spoon, icon, the gexlapı

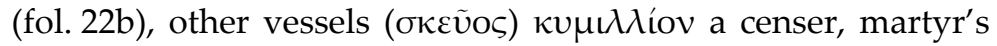
relics at the translation of the same (fol. 30), prayers for those about to journey by land and by sea, prayers before and after food $(34 b-T u k i)$, at the offering of the first fruit (36b) at lay-

(13) AL-MUHARRAQI, كتاب دلال أسبو ع الالام, p. 126.

(14) W. E. CRUM, Catalogue of Coptic Manuscripts in the British Museum, London, p. 357-358, Number 849. 
ing the foundations of a house, on beginning to live in a new house (40) at sowing (41) at the grape-harvest (incomplete 42).

OYEYXH EXEN NHEөOY(D) е(уєеп()еммо

صلاة على من يريد يسافر الى الغربة يقولما الاسقف في البر

(Fol. $\overline{\mathrm{P}} \overline{\mathrm{S}} \overline{\mathrm{S}}$ v.) $\Pi \overline{\mathrm{\sigma}} \overline{\mathrm{C}} \phi \dagger \overline{\mathrm{i}} \overline{\mathrm{C}} \Pi \overline{\mathrm{X}} \overline{\mathrm{C}}$

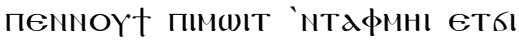
(1)d pic)T

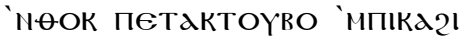
Tнрप OYO2 акTа2Оч EPdTप

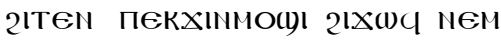
NєкдПостолос єөОүав

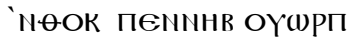
'NOYаггелос 'N2ІрнnікоN gdXwOY 'NHEKEBIdIK EपCWOYTEN 'мПОҮMШІт оYО2 COTOY EBOג2d GIMKA2 NIBEN 'nте †хом* (fol. $\overline{\mathrm{P}} \overline{\mathrm{Z}} \mathrm{r}$.) 'NANTIKIMENOC NEM OүEПIвоYגH 'NTE 2анршм еүгшо

OYO2 GIMUIT NWOY SEN MWIT

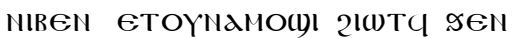
пекрап Mape nоY2вноүІ тнроү шюп еүшоү 'мпекран єөоүав neM OYXal 'nTE nENץYXH neM

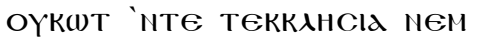
пєКגdOC

хе'нөок петен2єлпіс пем пеNтахро nем пенманфит* (fol. $\overline{\mathrm{P}} \overline{\mathrm{Z}} \mathrm{V}$ v.)
A prayer for those who wish to travel ${ }^{15}$

[by land, the bishop says]: ${ }^{16}$

Lord God Jesus Christ the True Way that leads to the Father

You, who purified the whole earth and You established [it] through Your walking on it with Your holy Apostles

You, our Lord, send a peaceful angel in front of Your servants, by straightening their way and rescuing them from all passions of the power of the hostility and the plot of evil men.

And guide them in all the ways that they walk in Your holy name. Let all their works be as a glorification to Your holy name and a salvation of our souls and edification of the Church and Your people

For You are our hope, our strength and our refuge.

(15) Lit. go to expatriation.

(16) Only in Arabic. 
OYO2 'HeOK пе еTANXal

'NMENYYXH EPOK OYO2

ENOYWPП NAK EПए)।

'мпाуепгмот є2PH ехен

2WBNIBEN

xє'мөокпепемноү十 єрє

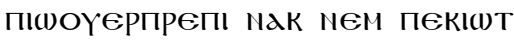

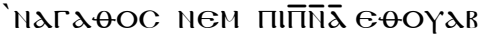
twoY

OYEYXH ЄөBE NHEONaMO(g) seN фIOM $\lambda \in \Gamma$

фNнв $\Pi \bar{\kappa} \overline{\mathrm{C}} \overline{\mathrm{IH}} \overline{\mathrm{C}} \Pi \overline{\mathrm{X}} \overline{\mathrm{C}}$ пеNNOY †фнет† 'nOYMWIт* (fol. $\overline{\mathrm{P}} \overline{\mathrm{H}}$ r.) sen фіOM nem OYMancy)П EqTaXPHOYT gen 2anMwOY EүXор фнетергемі еводгітеN

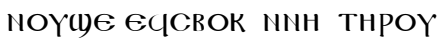

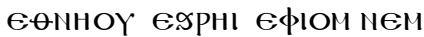
NIIPPOY OYO2 ET(y) 'NянTOY.

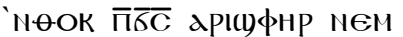
мекевідік оүо2 арігемі 'ммшоү gen OYHal nem OYMETMaIPڤMI apIEחITYMa[] 'N2WB NIBEN NEM Tарахн NiвеN * (fol. $\overline{\mathrm{P}} \overline{\mathrm{H}}$ V.) neM xосем NIBEN EөNatwoYn

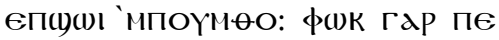
фІом: NEM NILPWOY OYO2 'NөOK

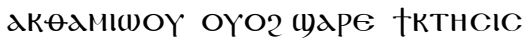
тнрс сотем 'nCd пете2NaK
And You are that we guide our souls and we send You thanksgiving for all things.

For You are our God, You are worthy of glory with Your Good Father and the Holy Spirit, now...

A prayer for those who travel by sea. He [the bishop] ${ }^{17}$ says:

Lord, Master Jesus Christ who guides on the sea and established dwelling upon the mighty waters, [You] who steer through simple wood [that is, a ship] for all those who goby sea and the rivers and those who sail upon in it.

You, Lord, accompany Your servants during sailing and steer them in mercy and love for all humankind. Disperse all thingsevery trouble and every storms which may rise before them. For to You belongs the sea and the rivers and You Yourself created them and the whole creation obeys Your will.

(17) Only in Arabic. 


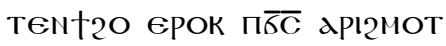

'NnEKEBIdIK 'NOYXINC)6HP

eceplay nеM оүөноY EndNEप

gEN ПOYMANMODI EपCOYTWN

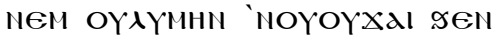

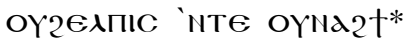

(fol. $\overline{\mathrm{p}} \overline{\mathrm{Q}} \bar{\theta} \mathrm{r}$.)

OYO26IMWIT gaxwOY 2ITEN

пाмнімı 'nте пекстдүрос пем

†сфрдгіс 'нте пек2мот еяоүн

епіүмна 'нте пекоүш()

2WB NIBEN COYTWOYNOY

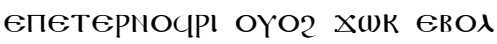

'NTENEYXH NEM NEN†2O

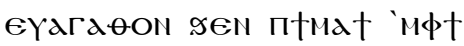

пекінт 'магдөос

фalete
We ask You Lord, grant Your servants a journey that is worthy and a good winds, straight paths [so that they arrive at] harbour of salvation in hope of faith.
And guide them through signs of Your Cross and the sign of Your grace to a harbour of Your will.

Make straight all things as it is pleasing [to You] and fulfil our prayers and our petitions as a good [thing] in accordance with Your good Father

To whom is...

\section{COMMENTARY}

- While the Litanies for the Travellers occur in many manuscripts, ${ }^{18}$ the last two prayers are not included in any printed books, and as far I know they are very rare even in manuscripts.

- It is worth mentioning that these last two prayers are said by the bishop and are included in a "Pontifical"19 while the other prayers are said by priests and deacons.

- These prayers are not included in a complete rite; such as the first two prayers which are part of the matins and vespers, and litanies said in the service of the Holy Week.

(18) To give examples from the collection of Saint Macarius preserved in Hamburg cf. L. STÖRK, Koptische Handschriten 4 (Die Handschriften der Staatbibliothek zu Hamburg, Teil 1, Liturgische Handschriften - Verzeichnis der Orientalischen Handschriften in Deutschland Band XXI,2), Stuttgart, 1996, p. 212, 228, 242-243, 247, 260.

(19) I. e. prayers to be performed by a Bishop cf. U. ZANETTI, "Bohairic Liturgical Manuscripts," OCP, 60 (1995), pp. 65-94. 
- Nothing is connected to the last two prayers. They are not accompanied by other actions such as anointing with oil or water, or the sign of the cross.

- The Greek loan words used in the texts are very common in liturgical texts, and therefore, do not help with dating the texts.

- The rarity of the last two prayers in the manuscript could mean that they have very limited use, such as the chant for welcoming the visitors in Scetis. ${ }^{20}$

The texts published above shed new light on the Coptic liturgy.

\section{SUMMARY}

Travelling was very risky in ancient times; hence there was a need to pray for the safe return of the travellers. In this paper will give an overview of the prayers for the travellers in the Coptic liturgy and we will publish for the first an edited prayer which is not attested elsewhere.

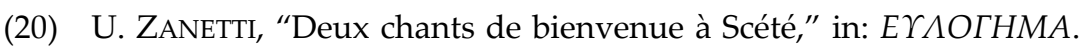
Studies in honor of Robert TAFT S. J. (Studia Anselmiana, 110), Roma 1993, pp. 593-611. 


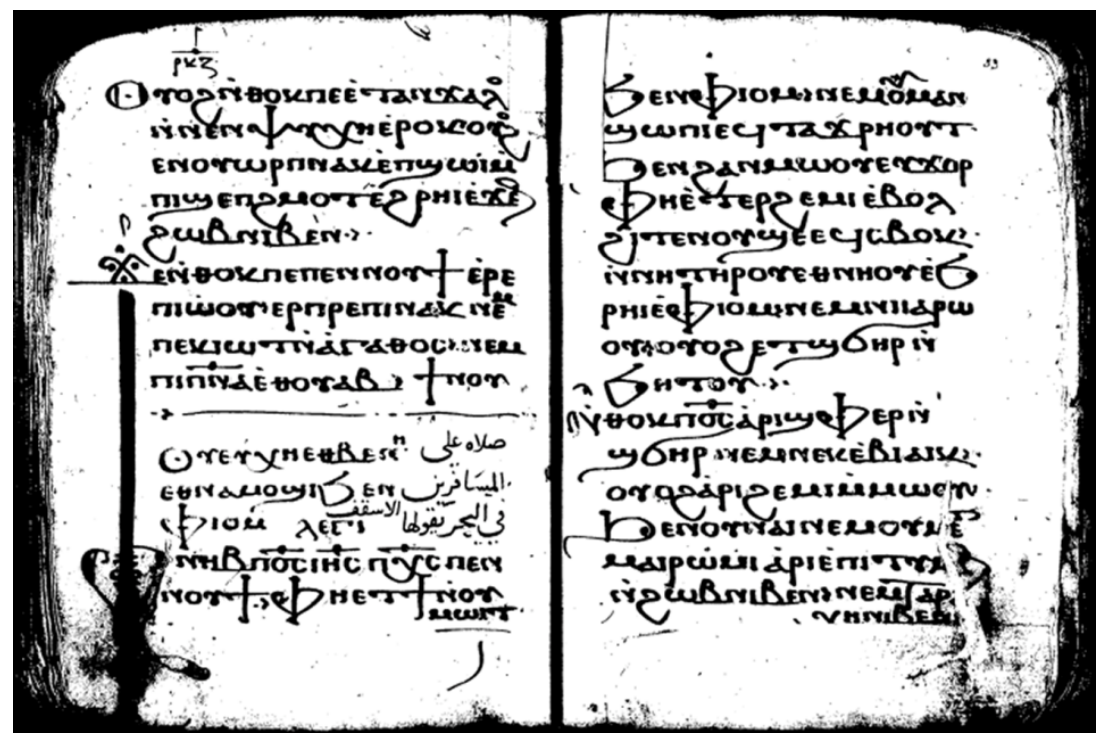

Ms British Library Or 435 fol. 127v-128r

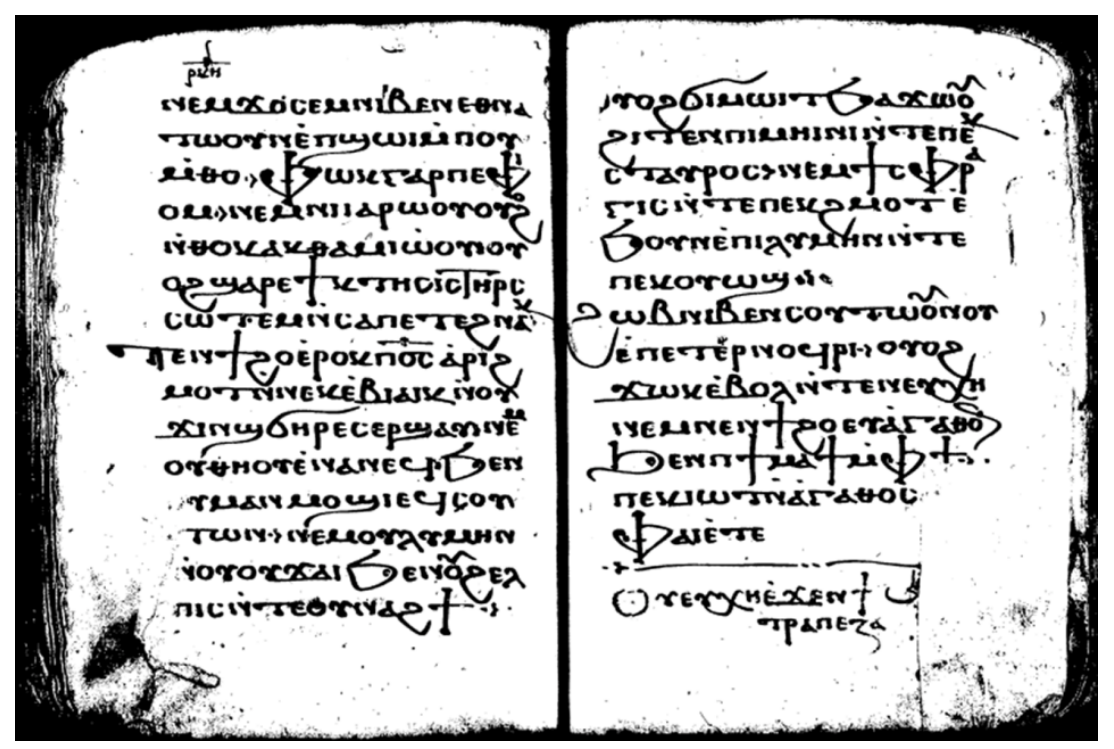

Ms British Library Or 435 fol. 128v-129r 